\title{
THE TROPICAL PRODUCTS INSTITUTE REPORT FOR 1961
}

$\mathrm{D}^{2}$ URING the next five years, the Department of Scientific and Industrial Research's Tropical Products Institute should expand its facilities to meet the increasing need for advice and investigatory work which is expected to result from technological and industrial development in tropical countries*.

Every year the Institute receives an increasing number of requests for specialist staff to visit tropical countries to give on-the-spot advice on problems connected with the use of natural products. The present commitments at the Institute often prevent the release of existing staff for this work. The Institute's Managing Committee considers that additional staff should be recruited so that experienced scientists will be available at relatively short notice for overseas investigations and, possibly, for the training of overseas laboratory staff in their own countries. Many tropical countries are beginning to set up their own research organizations with facilities for undertaking some investigations which previously would have been carried out at the Tropical Products Institute. However, the lack of suitable trained staff is still a problem, and it is recommended that opportunities for training them should be provided at the Institute in London.

The Director reports more than 960 inquiries for advice and assistance from 65 countries during 1961 . About 20 per cent of these inquiries related to marketing, trade and economic aspects of various tropical commodities. A further 30 per cent were concerned with processing methods and machinery, packing, storage and transport and the capital, plant and labour required for the establishment of small industries.

Among the investigations was one which may lead to a new coffee industry in British Guiana. For the first time an 'instant coffee' has been made from Liberica coffee beans grown in British Guiana. This was done during an investigation to find out if a local 'instant coffee' industry could provide an additional market for the increasing production of Liberica coffee beans, almost the only remunerative crop that will grow in the peaty soils of the British Guiana plantations. Coffee infusions were prepared at the Tropical Products Institute from two blends of Liberica and Robusta coffees. The powders proved to be of good flavour, the objectionable tang normally associated with Liberica coffee being largely removed during the processing operations. It would seem, therefore, that an acceptable 'instant coffee' could be manufactured from this coffee bean, with or without the addition of Robusta coffee. As a result the British Guiana Government has asked the Institute to obtain an estimate of the cost of a machine to prepare 'instant coffee', and plans for a suitable factory building, including machinery layout.

Other research workers examined an African weed to see if it could be used as a new source of oil. The seeds of Trichodesma zeylanicum (a member of the borage family), which grows as a pernicious weed in many parts of Africa, and especially on maize farms in Northern Tanganyika, may now

* Department of Scientifie and Industrial Research. Report of the Tropical Products Institute 1961: the Report of the Tropical Products Institute Committee with the Report of the Director of the Tropieal Products Institute. Pp vi + 37. (London: H.M.S.O., 1962.) 3s. net. prove to be a commercial source of oil. Investigations have shown that the seed contains about 30 per cent of a drying oil, similar to linseed oil, which, if it could be produced economically, might be used in the paint. linoleum and leather industries. This oil content is low compared with major oil-producing crops such as groundnuts (about 50 per cent), copra (some 60 per cent), and linseed (about 40 per cent), but it might be improved by plant breeding, as has been done with linsoed. As the seed contains supinine, an alkaloid which causes liver damage, the extracted meal is not suitable as an animal feeding material.

Cloves are Zanzibar's biggest export, providing about three-quarters of the world's supply. The islanders are largely dependent on this spice for their livelihood, and efforts have been made to find new uses for cloves so that the local economy can be improved. Clovebud oil, which is responsible for the aroma and flavour of cloves, is now being re-examined at the Tropical Products Institute with the use of now chemical techniques which may reveal the presence of components overlooked or wrongly identified in earlier analyses.

Although regular spraying of tea bushes with DDT is not a normal practice, it is important to know to what extent DDT persists in tea, both before and after processing, and in any infusion prepared from it, since such sprays are occasionally used. Research workers at the Tropical Products Institute have found that, while a large proportion of DDT present in the green leaf persisted throughout all stages of processing, only very low levels could be detected in infusions. This was so even when levels of DDT were much higher than those likely to be encounterod in com. mercial practice. A similar study of sacks of whole root ginger, sprayed with DDT in Jamaica, showed that the levels of DDT persisting on the ginger after storage were sufficiently high to suggest that this insucticide should not be used for the protection of large stacks of ginger without further investigation. Tests with malathion, however, showed that the persistence of this insecticide was much lower than that of DDT and that contamination of stored ginger would be only slight if the insocticide were applied at normal rates.

Experiments at the Tropical Products Institute may lead also to a new industry in West and Central Africa, South Amorica, India and other sub-tropical countries. Large quantities of groundnut shells, or husks, have no industrial use at present and disposal is difficult. They do not burn easily, nor do they rot quickly enough when returned to the land. Preliminary trials have produced an experimental particle board which is technically adequate and cheap to produce.

There are three important reasons why this industry could be developod in these eountries with economic advantage. There is an abundant supply of the raw material in areas where there is often a shortage of low-priced building and furniture materials. No machinery would be required to reduce the shells to suitable sized particles, and the shells would be sufficiently dry when produced to be made into board without further drying. Preliminary trials are also in progress using rice hulls, coir waste, bagasse and other materials. 